\title{
Gratuitous Deviation From the Terms of Form Contracts: Scandinavian Insurance Companies' Administration of Deferred Acceptance- of-Risk Clauses
}

Kriut S. Selmer

Modern industry and commerce have brought radical changes to the mechanism of contract. Legislators and lawyers to a great extent still look upon a contract as a bargain which emanates from negotiations between two individuals who are trying to influence the final result in accordance with their interests. The fact is, however, that the bulk of the contracts in a modern community are made without very much negotiation. One party-the customer-is free to choose the type of thing or benefit he wants, but the other party usually dictates the other conditions. This tendency has given rise to special legislation in all civilized countries to establish the general contractual pattern which a certain industry should apply, often by means of mandatory rules.

In most fields, however, there is still left a considerable degree of freedom, not a freedom to negotiate and frame individual contract terms, but a freedom for the stronger party to insist on his general terms. These terms will invariably form the basis for the legal relations between the industry and the public and will obtain much the same character as statutory law. Just as public authorities administer public law in their dealings with citizens, the great firms and industries administer their standard contract forms. Given the enormous number of individual decisions that have to be made, legal proceedings will be the rare exceptions in private business as well as in public administration. The executive officer of a big company basing its commerce on standard contracts therefore will, like the public administrator, distribute benefits and impose liabilities in accordance with legal texts, and the persons with whom he deals will more often than not have little legal knowledge and little insight in this particular area of administration or business.

Knut S. Selmer, Professor of Insurance Law, Oslo University, Norway, received a law degree in 1949 and a Dr.Juris. in 1958 from Oslo University. Professor Selmer originally gave this paper at the Scandinavian-American Legal Seminar at Hasselby Castle, Sweden, in the summer of 1965. 
No more than his colleague in public administration will the executive officer of a big private company attempt to twist the wording of the text to the benefit of the party he is representing. Deviations from the strictly legal solutions will tend to go the other way; there is ample proof that the executive officer will be under strong pressure, induced partially by competition, to grant the customer greater benefits and impose upon him fewer liabilities than he might have done if he had adhered strictly to the texts. This tendency is probably found in private business more often than in public matters, where financial and other controls will be more rigid. In the Scandinavian languages this tendency to deviate from standard contract forms to the benefit of the individual customer is called kulanse. Although English apparently lacks a corresponding word, "gratuitous deviation" or "inclination to pay ex gratia" would probably come nearest to the meaning. The phenomenon is a knowing abstention from enforcing the rights which a contract gives a party, rather than a settlement of a dispute about interpretation of ambiguous terms in the contract.

The problem concerns all industries which deal with the public at large and which avail themselves of standard contract forms. These conditions are characteristic of the life insurance business, which is the focus of this article. There are three situations in which a life insurance company has a right to contest a claim but where its acting offcers may be tempted to pay ex gratia. The first occurs when the applicant has concealed material facts or has given misleading information regarding his health. The second situation arises when the applicant has not paid the premium on time. The third occurs when the person on whose life the insurance is taken out has died before the company's risk attached. This third situation is the object of our attention. ${ }^{1}$

1 In the first of these situations, the stipulations of the insurance contract will usually be of little importance. The duty of the applicant to give full and correct information and the position of the insurer when there is a breach of this duty are important parts of the general background law. The law varies somewhat from one country to another, and there are particularly differences as to whether a concealment or misrepresentation has to be substantial and material and whether the insurer may contest the policy when the applicant has made his misleading statements in good faith. When, as is the prevailing rule, there is a good claim unless the applicant may be personally blamed for having made a misrepresentation which is material from the insurer's point of view, there is reason to believe that the insurance companies make use of the possibilities offered by the background law. There is probably no inclination to be generous towards an applicant who has shown carelessness or forgetfulness in ascertaining or stating the facts, and the survivors will generally be held responsible for the faults committed by the deceased. It may be that the companies do not insist on specified warranties with the same perseverance, especially when there is no suspicion of fraud or carelessness. Such tendencies cannot, however, be studied in the Scandinavian countries, where warranties are mainly prohibited. See HellNer, Exclusions of RisK and Duties Imposed on THE INSUREd (1955).

Nor does the second situation call for special attention. Forfeiture clauses are standard 
There are several stages in the conclusion of a contract for life insurance: the company's agent comes to see the prospective applicant; the applicant fills in the application blank; the medical examiner-if necessary-states his observations; the application is scrutinized and accepted by the company; the policy is issued; the policy and a request to pay the first premium are sent to the applicant; the first premium is paid. Somewhere in the course of this process the insurer will be contractually bound in the sense that he will have a duty to issue the policy and assume the risk for which the parties have negotiated. And somewhere in the course of the process the risk will attach.

The first question-whether the insurer is bound by the contract or not-must be decided in accordance with the general law of contract, irrespective of whether the parties know these rules or have them in mind. The exact moment when the insurer assumes the risk, however, is a basic provision in the contract itself. Unless otherwise provided by statute, the parties may make any stipulation they want in this respect. The insurer may assume the risk retroactively or only from some future moment.

The clauses bearing upon the attachment of risk vary greatly.2 $\mathrm{A}$

provisions in all insurance policies. A person who does not pay what he owes in due time is by definition at fault. Public interests are protected by statutory requirements that the insurer must give written notice when the premium falls due or that the insured should be granted certain delays. Probably life insurers abstain occasionally from invoking forfeiture clauses which they have a legal right to invoke as, for example, when payment was prevented by circumstances clearly beyond the control of the insured. This, however, does not interfere with the basic contractual mechanism, nor does it entail consequences that may be questionable from a general point of view.

2 Most American life insurance policies provide that the risk does not attach until the home office has approved the application and until the policy is delivered to the applicant. See Kessler, Forces Shaping the Insurance Contract, in Conference on Insurance 1, 20 (University of Chicago Law School Conference Series, Nov. 14, 1954). But some American companies also use binding receipts that provide some coverage immediately upon application for life insurance: "When the first premium is paid by the applicant with or at the time of the application for life insurance, he is ordinarily given a receipt, the form of which falls into one of two general categories. The first, called the 'approval' form, purports to put the insurance in force immediately, but on condition that the application be approved at the company's home office on the plan, at the rate, and for the amount applied for. With the other, the 'insurability' type, the condition precedent to immediate coverage is insurability of the proposed insured under the rules and practices of the company on the date of the receipt or the medical examination, whichever is later, at the rate, on the plan, and for the amount applied for." O'Neill, Interim Coverage: Conditional Receipts, 1964 U. ILL. L.F. 571, 574-75. Courts in almost all American jurisdictions have upheld such clauses when they were clearly phrased in understandable language and have held there was no interim coverage unless the condition precedent was fulfilled. When the clauses are ambiguous, most courts would resolve the ambiguity against the insurer. Id. at 590-91. See generally, Appleman \& Appleman, Insurance Law and Practice §§ 101-12, 131-43, 171-75 (rev. ed. 1965); Maclean, Life Insurance 569 (1962); Havighurst, Life Insurance Binding Receipts, 33 ILI. L. REv. 180 (1938); Kessler, supra at 
clause frequently inserted in Norwegian life insurance contracts runs: "The insurance shall be operative as soon as the policy has been issued and the stipulated premium has been paid, provided that the insured person is alive at this moment." But a number of companies waive the cash payment condition in contracts for the so-called level premium insurance. In this situation, therefore, the basic condition is that the insured must be alive when the company issues the policy; if he dies before the issuance of the policy, the company has no legal obligation to pay his beneficiaries. Swedish companies usually make no provisions concerning the attachment of the risk, but instead rely on a statute which provides that the risk shall attach when the company sends its acceptance of the application. ${ }^{3}$ Danish and Finnish conditions are variations of the Swedish rule. In Denmark the insurance usually runs from noon on the day when the company decides to accept the insurance and confirms its decision in writing upon the application, whereas the liability of the Finnish company will start twelve hours later-from midnight on the day of acceptance.

There are good reasons why the company should not bear the risk until the application has been scrutinized and the insurance has been accepted by a competent person in the company's central organization. The insurer cannot leave it to the life insurance agents to judge the health of the applicants and accept the risk on behalf of the insurer, for an apparently innocent disorder may be a symptom of a serious disease which will either make insurance impossible or necessitate surplus premiums and extraordinary arrangements by way of reinsurance. It is of vital importance to the insurer that the risk be judged-in advance of assumption of risk-by a medically trained person so that the company has a chance to seek supplementary information, to arrange a medical survey, and to decline the acceptance of uninsurable risks. A contractual mechanism which did not give these opportunities to the life insurance companies would be intolerable.

Despite the existence of a specific provision calling for delayed acceptance of risk and despite the valid commercial reasons for this provision, Norwegian, Swedish, and Danish insurance companies have not

19-21; Wilkinson, Binding Receipts-Three Decades Later, in AMrerTCAN LIFE CONVENTION: Legal Section 18 (1949); Comment, Life Insurance Receipts: The Mystery of the NonBinding Binder, 63 YALE L.J. 523 (1954); Comment, Operation of Binding Receipts in Life Insurance, 44 YALE L.J. 1223 (1935).

3 Swedish Insurance Contracts Act $\$ 11$. This section states that the risk shall run from the moment when one party sends his acceptance of the other party's offer. The application for insurance is regarded as the offer; the company's acceptance of the application as the acceptance. Failing proof to the contrary, the letter of acceptance shall be deemed to have been sent at noon. 
insisted on enforcing this provision and have paid the sum applied for when the applicant dies in the critical period before risk has been formally accepted. ${ }^{4}$ In Norway 5 and Sweden a condition for payment is establishment beyond doubt that the contract would have been concluded with the premium offered and the sum applied for. Danish insurers, on the other hand, make ex gratia payments based on guesses about the results of further negotiations. If, for instance, the answers in the application blank are of such a nature that the company would have charged a surplus premium, the company will pay the amount that might be insured at the premium offered by the applicant.

This generous practice is upheld by strong notions of fairness and equity within the life insurance industries. In Norway, the question of an ex gratia payment of N. kr. $400,000(\$ 60,000)$ to the relatives of a man who perished in the mountains while his application was being processed by the insurer was submitted to a board consisting of eight managing directors of important life insurance companies. The board unanimously held that "it would be in conformity with good standards in Norwegian life insurance to regard this insurance as being operative when the applicant disappeared."6 And a Swedish life insurance executive has recommended that "the question of payment in similar cases ought to be resolved according to equitable principles"; he even intimates that one may take into consideration such circumstances as the economic position of the dependents and their need of support. ${ }^{7}$ Motivations of this more social character, however, play a comparatively modest role in the practice of the companies. The ex gratia payments are mainly used in order to repair the general injustice which in certain situations is inherent in the prevailing conditions of the contracts.

4 XIV NORDISKE LIVSFORSIKRINGSKONGREs I KøBENHAVN (1964) [REPORTs, 14t7 SGANDINAviAN CONGRESS OF LIFE INSURANCE IN COPENHAGEN (1964)]. This contains results of a survey of the practices of Scandinavian life insurance companies in 1963-1964. In Finland, ex gratia payments are apparently not made.

5 Norwegian companies use two devices which largely eliminate the need for ex gratia payments. According to the conditions of the contracts of two of the thirteen Norwegian companies, the insurance is deemed to have taken effect immediately upon the signing of the application and the simultaneous payment of the first premium, provided that the applicant is later found to have been an insurable risk at this time. Id. at 33. The other device, which has been developed recently and which has been adopted by most companies, consists in the sale of "provisional policies." The agents sell, against cash payment, a policy covering for a period of two months death by accident or sudden illness; this will usually be enough time to accomplish the investigations and formalities. Id. at 34-35. None of these methods, however, gives a full and perfect remedy, and hence there will still be some situations where an ex gratia payment is the only way to obtain the result which is considered fair.

$6 I d$. at 44.

$7 I d$. at 63,65 . 
The reasons for these ex gratia payments are several. In almost all cases everything that happens from the time the application is signed until the time the risk is accepted is a mere formality. The applications and hence risks which are accepted without medical examination of the applicant have steadily increased as a means of rationalizing the company's procedures. The great majority of the applicants are insurable on the usual terms. In fact, rarely will the medical officer of the company question the health of an applicant and recommend refusal of the insurance or supplementary inquiries. Thus, in those cases where the insured would have had his insurance had he not died before the formalities were completed the contractual mechanism seems unfair and unwise. The survivors may also point to public social insurance where coverage automatically exists from the moment when one takes a job or enters a group where such cover is compulsory; here even formal application is unnecessary. Why, they may ask, does life insurance, which undoubtedly may be seen as one of the great social institutions of our time, avail itself of an antiquated contractual mechanism inherited from a time when a contract was the result of bargaining between two equal partners?

One good reason for making ex gratia payments is the desire to further the company's public relations. An ex gratia payment of some importance will soon be known in the area of the residence of the recipient and will tend to establish a good reputation for the company. Being known as a company that treats its beneficiaries "generously" or as a company that "does not bother with legal niceties" may induce people to buy their insurance from this particular company. The company's local representative will usually have recommended a liberal course, and the backing that he gets from his principal will strengthen his position and attract new customers. When, as is especially the case in insurance, the companies offer almost identical contract terms, the choice of local representative is often more important for the prospective client than the choice of company.

Considerations of public relations will also point toward settling the case out of court if there is the slightest doubt as to the outcome of legal proceedings. Companies dealing with the public are vulnerable to criticism, and a lost case means lost prestige. And even if the case is won, it may strain the company's reputation if the decision rests on the application of a clause or a rule which the public regards as unfair or unjust. Thus, even when the legal position is beyond doubt, the company may be tempted to make payment.

Avoidance of litigation is, of course, also prompted by the desire to eliminate the costs and risks of litigation. Litigation always costs money 
and occupies the time of people who might have done other and more useful work. And litigation always creates the possibility of a decision adverse to the insurer's interest which may return to haunt it in the future. Even if a decision is based on the circumstances of the particular case, there is the risk it will be relied upon as precedent in similar cases in the future. Thus, it may be safer to pay the claim today in order to have a freer hand the next time a similar question arises. ${ }^{8}$

A strong element of charity may also be inherent in an ex gratia payment. The customer as a rule is the little man in society. In life insurance the surviving relatives may be poor and ill; in casualty insurance a loss may have occurred that will ruin the insured if not compensated. Helping people who are in great need of economic assistance has given many life insurance executives a feeling that they are representing charitable institutions and has made them especially open to appeals to charity or generosity. Though commercial motives may be and often are disguised in the veil of charity, one would do injustice to the men in life insurance if one categorically denied the element of spontaneous charity in many of their dispositions.

The practice of ex gratia payments may easily be reconciled with the principle that one should alleviate poverty or economic need in as many instances as possible. But there is much poverty in the world, and the funds of life insurance companies cannot be distributed according to the needs of individuals. The only possible justification of the ex gratia payment is that the person almost has a legal claim against the company, and not that he stands in need of the money, for there may well be others who are in greater need than himself. If we maintain, however, that life insurance should be paid in accordance with contractual terms, rather than according to economic need, it is necessary to ask why the people who only came near to having a claim did not actually get a claim. If it is due to weaknesses inherent in the contractual mechanism itself, defects which the man in the street will re-

8 There is a possibility that a consistent practice of making ex gratia payments may alter the law itself by creating a legal duty without any corresponding alteration of the contracts. Section 34 of the Norwegian Insurance Contracts Act, which is substantially similar to provisions in the Danish and Swedish acts, reads: "When an insurance contract contains a stipulation which is not found in this Statute and which leads to results which are manifestly unjust and irreconcilable with good insurance practice, such provision shall be set aside." If a Scandinavian company rejects a claim falling clearly within the generally accepted "ex gratia sphere," the claimant may obtain from other companies a statement that they would have regarded an ex gratia payment to be appropriate and in accordance with good standards of life insurance practice. With this industry opinion the beneficiaries will have a fairly good chance to enforce their claim in the courts. The fact that there are no reported cases of this kind probably only reflects the stability and universality of the practice of making ex gratia payments. 
gard as injustices, there is a reason for correcting the situation. But this means revising the defective mechanism, not exercising individual charity. If, on the other hand, a person has lost his claim by the application of generally accepted principles of law, there is no apparent reason why his particular need should be satisfied at the cost of the company.

Another supposed justification for ex gratia payments is the difficulty in framing contracts which in all situations lead to equitable results. Restrictive terms imply that the company has a legal right to reject some claims that ought to be honored; liberal terms, on the other hand, may compel the company to accept claims from persons who are in no way worthy of protection. By using restrictive terms and adding $e x$ gratia payments where the contracts fall short, a company may obtain a maximum of just and equitable decisions. But this argument presupposes that the company is able to reach the "right" and "just" decision in every situation. This is definitely not so. Life insurance conditions and other standard contracts are always written so that they can be easily administered, and hence claims depend on certain simple facts which are easy to establish. To attempt to reach a "right" or "just" result requires an examination of the individual circumstances of every case, a task for which insurance companies are less capable than the courts.

There is in fact reason to believe that the fair distribution of justice will be much more difficult under a system of ex gratia payments. A company choosing this course imposes on itself the burden of being equally generous towards all its customers. This does not mean that everyone who is asking for money should get it. But the company must be consistent; it cannot accept one claim today and reject another claim tomorrow in situations which are substantially similar. It is of course not very burdensome to proclaim that one is consistent. But the diffculty is to decide when the facts of a new case are so similar to those of a preceding one that the outcome ought to be the same. As long as all decisions are taken in accordance with the contractual terms, it is fairly easy to be consistent; but once a system of "ex gratia situations" is created, fair administration becomes considerably more complex. There is much wisdom in the bureaucrat's unwillingness to deviate from the letter of the law or the contract, for it protects him against a situation in which he either will lose control or will be compelled to do gross injustice to a person who in good faith has relied upon a liberal practice.

Even if the companies were able to distribute their ex gratia pay- 
ments in a consistent manner, there is reason to believe that their customers would not get equal treatment. In order to achieve complete equality and fairness, all persons who had a "right" to an ex gratia payment would have to present their claims. But they probably do not do so, for the conscientious citizen who has read his contract carefully will refrain from claiming money which he has obviously no right to claim. Those who get the payments may thus be the cantankerous and unscrupulous. This self-selection of claims brought to the company's attention makes it improbable that full justice will be obtained.

In summary, an extended use of ex gratia payments is unwise. It places an administrative burden on the insurance companies, and it is doubtful whether it promotes the high degree of equality and fairness that is desirable in the relations between life insurance companies and the public. A stricter application of the contract terms would, of course, occasionally lead to decisions which might seem hard and bureaucratic. But this might in turn lead to a more frequent revision of the terms, whereby the public would be given as a right the position which is intuitively felt to be fair. 